International Journal of Business Governance and Ethics

Manuscript ID: IJBGE-7877

\title{
Drivers of Convergence/Divergence of Corporate Governance Codes of MENA Countries
}

\author{
Dr Ali Uyar \\ Associate Professor in Accounting \\ La Rochelle Business School, France \\ Email: aliuyar@hotmail.com
}

\author{
Dr Hany Elbardan \\ Senior Lecturer in Accounting and Finance \\ Bournemouth Business School, Bournemouth university, UK \& \\ Faculty of Commerce, Alexandria University, Egypt \\ Email: hany.elbardan@gmail.com
}

Dr Ahmed Yamen

Assistant Professor in Accounting

Ain Shams University, Faculty of Commerce, Cairo, Egypt \&

American University of the Middle East, Kuwait

Email : ahmed.Yamen@aum.edu.kw 


\title{
Drivers of Convergence/Divergence of Corporate Governance Codes of MENA Countries
}

\begin{abstract}
This study aims to fill an existing gap in the regional corporate governance research by investigating the extent of and the drivers behind the convergence or divergence of the corporate governance codes among MENA (Middle Eastern and North African) countries comparing to the globally known OECD (Organization for Economic Cooperation and Development) principles of corporate governance. We build a comprehensive database of codes of corporate governance for a sample of 16 countries, and 83-item checklist derived from OECD Principles of Corporate Governance for content analysis. The results of the study revealed that the convergence level of the codes among the countries and compared to OECD principles significantly varies among countries, ranging from $31 \%$ to $73 \%$. The results show that the adopted governance principles in the codes are 'decoupled' from legitimation concerns and focus on efficiency goals. The macroeconomic factors of MENA countries do not consistently reflect the convergence score of the codes with the OECD Principles. The institutional quality factors of MENA countries are not aligned with their codes. A deviation between the governance indicators and the quality of codes is observed in most of the MENA countries. This study adds to the literature on corporate governance codes in one of the most distinct regions of the world. To the best of our knowledge, this is the first study that systematically analyzes the convergence/divergence of the corporate governance codes of MENA countries by benchmarking OECD Principles and identifying the factors behind the convergence/divergence. The study provides several important implications for the regulators, firms and other stakeholders. The findings suggest some improvements in the corporate governance codes of the countries in the sample and draw regulators' attention to important developments of corporate governance codes to enhance economic efficiency and legitimacy. These improvements include incorporating capital market authority into the code development process to better consider the expectations of investors, weakly structured sections of the codes need to be strengthened in the next revisions and MENA countries need to revise their codes in a timely manner.
\end{abstract}

Keywords: Corporate governance codes, Convergence/Divergence, MENA countries, Institutional theory. 


\section{INTRODUCTION}

Corporate governance plays a fundamental role in allocating resources across firms and even across countries, thus affecting how wealth is distributed between and within national economies (Aguilera et al. 2016; Schiehll and Martins, 2016). Moreover, corporate governance impacts how corporate power is channeled for the good of society. Corporate governance codes are the main references that shape the relevant practice of firms in nations. One of the main ongoing research streams is the debate around corporate governance codes convergence or divergence (Krenn, 2016).

Although some previously published corporate governance studies related to the MENA (Middle Eastern and North African) region exist, they are mainly about individual or selected countries' or firms' practices at the micro level (e.g. Bremer \& Ellias, 2007; Farooq \& Chetioui, 2012; Farooq \& Seffar, 2012; Kamal Hassan, 2012; Farooq \& AbdelBari, 2013; Al-Malkawi et al., 2014). This paper covers the topic from the macro-level and regional-level standpoint through examining the corporate governance codes for all the sixteen MENA countries. There are several reasons for studying corporate governance codes in this specific region. First, the MENA region is one of the unique regions in the world, it not only shares similarities in culture, the absence of democracy, identical religion, and the same language, but also some important dissimilarities in legal, economic, institutional and governance foundations. Second, as the region's oil-importing countries attempt to attract investors and oil-exporters attempt to diversify their oil-dependent economies, they seek better governance and regulatory environments.

Even though existing studies on corporate governance practice have generated a wealth of knowledge regarding issues related to corporate governance codes and practices in different regional, legal, national contexts, they reveal gaps and raise many issues for research in the codes' convergence or divergence and the drivers behind in many regions. Studying this in MENA countries may generate important and different findings than developed countries since they have different economic, legal, political and institutional backgrounds. Piesse et al. (2012) note that very little attention has been drawn to the corporate governance systems within MENA countries even though Anglo-American, Continental European, and Asian models of corporate governance have received great attention from researchers. Therefore, MENA countries deserve special attention since their political, economic, and ownership structures have many peculiarities. They may diverge from the Anglo-Saxon model in some respects; hence, the "one size fits all" approach to corporate governance, particularly the Anglo-Saxon model, might not necessarily be the right approach for these countries (Davies and Schlitzer, 2008). However, convergence on the main dimensions of corporate governance such as more independent and diverse boards, the establishment of board committees, and higher transparency and disclosure may be the preferred way forward. In addition, the development of good corporate governance codes for Arab countries, where legal investor protection is weak, and ownership concentration is high, is crucial in protecting minority shareholders from abuse by controlling shareholders (Omran et al., 2008).

We aim to identify the degree of convergence and divergence of corporate governance codes of the MENA countries, and the drivers behind. Additionally, we aim to assess the coverage of corporate governance codes of these countries by comparing them to the OECD (Organization for Economic Cooperation and Development) Principles of Corporate Governance (OECD Principles, 2015) as a benchmark. We selected the OECD Principles since it was the first 
international body to produce a set of globally accepted standards of corporate governance (Solomon and Solomon, 2004). In doing so, we attempt to contribute to the improvement of the codes of these countries by indicating areas for further improvement.

Furthermore, we investigate whether the driver of the codes is efficiency or legitimacy concerns (Aguilera and Cuervo-Cazurra, 2004; Zattoni and Cuomo, 2008). We aim to do this by analyzing economic factors and public governance factors of these countries about the development of the corporate governance codes and their principles. However, because some countries in the sample have been undergoing internal turmoil, some variables among the economic factors are missing. Notwithstanding, we draw significant conclusions with the available variables.

The study aims at answering the following research questions:

R1: How do the corporate governance codes of MENA countries converge with or diverge from one another?

R2: How do the corporate governance codes of MENA countries converge with or diverge from the OECD Principles (2015)?

R3: What are the main drivers of the divergence/convergence of the corporate governance codes of MENA countries? Are they efficiency or legitimacy related?

The remainder of the paper is as follows. The second section presents the theoretical background and provides a literature review regarding corporate governance codes development in various jurisdictions and convergence/divergence of codes. The third section provides economic and governance outlook of MENA countries. The fourth section outlines the methodology of the study which is followed by the results in the fifth section. Finally, the last section discusses the results, provides conclusions and implications and sets the limitations of the study.

\section{CORPORATE GOVERNANCE CODES BACKGROUND}

Monitoring management performance in developing countries could be less effective where the institutional environment is less developed and obtaining information about companies, and their management performance is more difficult. Therefore, establishing a set of rules that describe how the management of companies should be monitored is essential to ensure that management maximizes the returns to investors. These rules may be legally enforced or voluntarily applied. Such rules constitute corporate governance codes, which outline recommendations about best practices and refer to issues such as shareholders' rights, the disclosure of information, stakeholders' rights, boards of directors' responsibilities and internal control systems. Codes have become a widely used means to encourage companies to increase their transparency and accountability. Moreover, many countries have developed corporate governance codes detailing best practices for the effective monitoring of management, which is essential to the stability of financial markets; however, no definitive set of rules have emerged. This could be partly because of the domestic influences within each region.

In Europe, the first code was established with the issuance of the Cadbury Report in 1992. Later, recommendations on codes were published by the Organization for Economic Co-operation and Development (OECD, 1999). National codes are generally issued for listed companies, although there are also codes designed for other organizations such as non-listed companies, familyowned companies, SMEs and commercial banks. Compliance with corporate governance codes 
differs between countries: It could be based on the "comply-or-explain" principle, which provides companies the option to deviate from code recommendations if they explain the reasons for doing so; it could be based on voluntary adoption and disclosure, or mandatory adoption can be required. With the worldwide adoption of corporate governance codes, researchers have devoted greater attention to investigate the codes' characteristics and recently to examine the rationale behind their convergence or divergence among countries (e.g., Krenn, 2016; Nizaeva and Uyar, 2017).

Prior literature has focused on the analysis of the content of specific national codes in a single country of certain European countries (e.g., Cromme, 2005 in Germany; Webb, Beck, \& McKinnon, 2003 in the UK), Russia (Roberts, 2004), Japan (Ovsiannikov, 2017) and other emerging economies (e.g., Nigeria, Malaysia). Some studies focus on the influence of codes issued by transnational institutions on the development of national corporate governance codes (Aguilera \& Cuervo-Cazurra, 2009). Other studies show that the content of the codes does not converge, and that divergence prevails worldwide (e.g., Collier \& Zaman, 2005; Hermes et al., 2006; Zattoni \& Cuomo, 2008; Cicon et al., 2012). One of the reasons for the divergence could be differences in national cultures. For instance, Humphries and Whelan (2017) investigate the relationship between the content of corporate governance codes and national culture for 55 countries. They find significant relationships between cultural dimensions and corporate governance code recommendations.

Most of the literature investigated corporate governance codes convergence-divergence debate focus on classifying corporate governance codes as belongs to the Anglo-American shareholder model or the Eurasian stakeholder model. However, Heugens \& Otten (2007) through a content analysis of the corporate governance codes of 38 countries, suggest other corporate governance systems classification based on five corporate governance logics - socially constructed, historical patterns of material practices, assumptions, values, beliefs, and rules. Moreover, adopting an institutional theory perspective, Krenn (2016) construct a theoretical framework to conceptualize convergence and divergence dynamics as simultaneous processes of institutional change and continuity, considering the influence of economic market forces, social embeddedness, and cultural forces. Krenn finds that convergence and divergence dynamics can coexist and lead to increased heterogeneity in corporate governance codes. This finding adds complexity to the debate and opens room for interesting research directions.

In the convergence-divergence debate, a limited number of articles have empirically analyzed and compared the content of different national codes or examined the impact of the codes issued by transnational institutions on the convergence/divergence of national codes (Cuomo et al., 2016). For example, Hermes et al. (2007) analyzed and compared the corporate governance codes content of seven Eastern European countries and showed that the content of corporate governance codes of countries is different when compared to best practices and is somehow shaped by forces related to country-specific characteristics of corporate governance systems. One of these country-specific characteristics is the type of issuer, which differs across countries. Therefore, analyzing the content of national codes, investigating the drivers behind their provisions and examining the impact of the codes issued by transnational institutions, such as OECD, on the convergence/divergence of national codes constitutes an important gap in the literature, because the outcomes may also have significant economic consequences. 
Although agency theory is the dominant theoretical framework in studying corporate governance codes at the company level, the institutional theory has been increasingly adopted in countrylevel studies (Cuomo et al., 2016). Institutional theory articulates convergence and divergence of the national corporate governance codes as processes of institutional change and offers a holistic perspective that considers the influence of economic market forces, social embeddedness and cultural forces (Krenn, 2016). Corporate governance codes reflect the institutional environment where they are developed (Aguilera and Jackson, 2010). This institutional environment includes the economic system, political system, and legal system. As such, the corporate governance codes should reflect the prevailing influences found in the institutional environment as well as the type of issuer. Greco, Ferramosca \& Marchi (2015) study the relationship between the types of issuer and the governance codes contents in the neo-institutional social theory perspective, using a global sample of over 70 national governance codes. They find that the national institutional settings shape this relationship. Aguilera and Cuervo-Cazurra (2004) show that the type of institutional pressure to adopt codes varies according to the type of issuer. When codes are issued by the stock exchange, it represents coercive pressure; when codes are issued by a managers' association, it represents mimetic pressure; when they are issued by others, it represents normative pressure. Aguilera and Cuervo-Cazzura (2004) provide a theory to explain countries' adoption of corporate governance codes. They argue that the adoption of codes may be based on both efficiency and legitimacy factors. Efficiency refers to the demand for codes from investors who believe that codes protect their interests. Legitimacy refers to pressure to adopt codes because of increased globalization and opened financial markets for foreign investors. When countries open their economy to foreign investment, they are expected to adopt international corporate governance practices to attract foreign capital. This proposed framework may be used to explain the content of codes that describe the practices of corporate governance.

Using this framework, the content of codes in the MENA region may be explained by referring to two sets of factors. Efficiency factors and institutional settings may influence the content of corporate governance codes. Differences in corporate governance systems may lead to divergence in the content of codes. Therefore, codes reflect the particularities of each country's distinct institutional environments. Legitimacy factors influencing corporate governance in MENA are globalization, the openness of financial markets for foreign investment, adoption of international standards and communications of international institutions such as the OECD. Legitimacy factors may lead to a convergence between the corporate governance codes of different MENA countries. However, if efficiency factors drive the content of codes, we may expect divergence instead of convergence of corporate governance codes among different MENA countries.

Even though the prior literature noticeably enriches our knowledge of the antecedents and consequences of governance codes, Cuomo et al. (2016) show that there are still several opportunities for significant contributions in this area because there is a growing interest in studying codes; the academic debate is still lively and will be in the coming years. Additionally, Krenn (2016) calls for more theory-based research regarding the drivers of the provisions in corporate governance codes as a promising avenue to examine the antecedents of the coexisting convergence and divergence in corporate governance codes at a national and regional level.

Our study replies to the research call by Cuomo et al. (2016) and Krenn (2016) to extend the studies in corporate governance codes to provide a careful examination of the codes' content. While prior studies have focused on the influence of corporate governance codes at the company 
level (Zahra, 2014) and few comparative studies have adopted an institutional perspective to examine the factors that drive the adoption of specific governance principles (Schiehll and Martins, 2016). This study reviews country-level corporate governance codes and investigates the divergence/convergence of corporate governance codes of MENA countries in light of the ongoing discussion with respect to the institutional forces that may drive the content of corporate governance codes. We use the OECD principles as our point of reference.

\section{ECONOMIC AND GOVERNANCE OUTLOOK}

\subsection{Economic Indicators}

In this section, we elaborate on the economic indicators of MENA countries to investigate their possible association with the development of the corporate governance codes in forthcoming sections of the paper. Therefore, the economic overview of the countries in the region is outlined using the following variables as detailed in table 1): oil exporters or importers, GDP per capita, growth rates, stock market development, and the depth of credit information to the private sector.

The adoption of corporate governance codes by a country is a signal that indicates a commitment to improving its corporate governance system (Aguilera and Cuervo-Cazurra, 2004). Among the primary receptors of this signal are trade partners, foreign financial market investors, and foreign direct investors. Therefore, there is a strong link between corporate governance and the promotion of equity markets and economic development (Paredes, 2005). Furthermore, Claessens and Yurtoglu (2013) emphasize that economic developments, internationalization, globalization in trade and finance, and the interconnectedness of financial markets are considered the impetus for the development of corporate governance codes. Thus, studying the macroeconomic indicators of MENA countries in relation to corporate governance code development is considered essential. The poor record of transparency, disclosure and reporting in MENA countries, which are the main pillars of corporate governance, is the main reason for the region to be overlooked by global long-term investors (Nadal, 2013).

MENA countries can be classified as either oil-exporting or oil-importing countries. The purpose of this classification is to investigate whether there is an observable difference among MENA countries in the development, revision, and content of corporate governance codes. The reasoning is that oil importers are more likely to attempt to attract foreign capital relative to oil exporters since the former do not have an oil surplus to support its economic development compared to the latter. This is proven in terms of foreign direct investment (FDI) as a percent of GDP in Lebanon and Jordan, which are both oil importers far ahead of other countries with 7.45\% and 5.14\%, respectively, whereas Qatar and Algeria, which are both oil exporters, have the least percentages at $0.87 \%$ and $0.78 \%$, respectively ${ }^{1}$, and is even below the world average of $2.68 \%$ (Table 1).

\footnotetext{
${ }^{1}$ Although Yemen is in Table 1, we prefer not to comment on its indicators due to the ongoing severe political turmoil for the past several years.
} 
TABLE 1

Economic indicators of MENA countries

\begin{tabular}{|c|c|c|c|c|c|c|c|c|c|c|}
\hline $\begin{array}{c}\text { 2010- } \\
2015 \\
\text { Average }\end{array}$ & 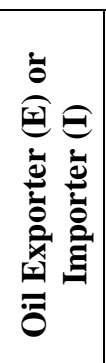 & 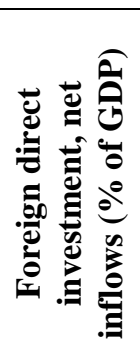 & 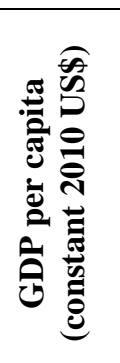 & 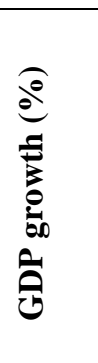 & 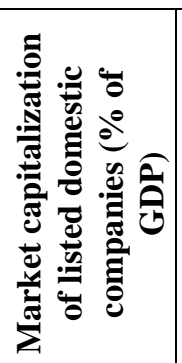 & 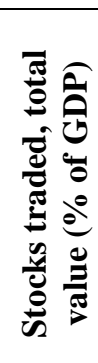 & 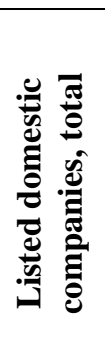 & 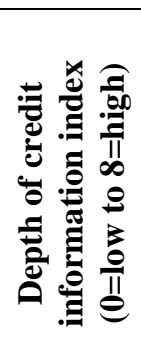 & 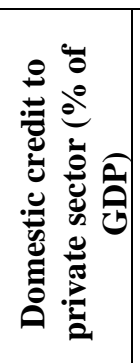 & $\begin{array}{c}\text { Population, } \\
\text { total }\end{array}$ \\
\hline Algeria & $\mathrm{E}$ & 0.78 & 4,614 & 3.40 & NA & NA & NA & NA & 16.57 & $37,829,951$ \\
\hline Bahrain & E & 1.25 & 21,084 & 3.81 & 65.02 & 1.24 & 44 & 6.67 & 68.14 & $1,331,584$ \\
\hline Egypt & I & 1.48 & 2,667 & 2.95 & 23.68 & 7.93 & 237 & 8.00 & 28.47 & $86,698,532$ \\
\hline Jordan & I & 5.14 & 3,993 & 2.64 & 85.68 & 13.86 & 245 & NA & 72.07 & $7,083,033$ \\
\hline Kuwait & E & 1.04 & 37,391 & 2.17 & NA & 16.52 & 153 & 6.00 & 69.64 & $3,492,860$ \\
\hline Lebanon & I & 7.45 & 7,855 & 2.74 & 27.99 & 1.78 & 10 & 6.00 & 95.55 & $5,100,490$ \\
\hline Libya & $\mathrm{E}$ & 1.56 & 7,535 & $(0.05)$ & NA & NA & NA & NA & 19.67 & $6,273,527$ \\
\hline Morocco & I & 2.70 & 3,056 & 3.94 & 55.13 & 3.80 & 75 & 6.00 & 68.29 & $33,229,216$ \\
\hline Oman & E & 1.50 & 17,168 & 3.52 & 46.55 & 5.40 & 115 & 6.00 & 46.80 & $3,722,075$ \\
\hline Palestine & I & 1.39 & 2,518 & 5.29 & 26.15 & 2.75 & 46 & 7.33 & 7.45 & 4,111,898 \\
\hline Qatar & $\mathrm{E}$ & 0.87 & 3,822 & 8.37 & 83.15 & 14.85 & 43 & 5.00 & 45.62 & $2,032,547$ \\
\hline Saudi & E & 2.19 & 20,445 & 4.98 & 60.10 & 57.16 & 160 & 8.00 & 41.89 & $29,833,850$ \\
\hline Syria & I & NA & NA & NA & NA & NA & NA & 2.00 & NA & $19,633,002$ \\
\hline Tunisia & I & 2.36 & 4,169 & 1.70 & 22.64 & 2.42 & 66 & 4.00 & 76.08 & $10,831,550$ \\
\hline UAE & $\mathrm{E}$ & 2.60 & 36,670 & 4.30 & 41.66 & 12.63 & 114 & 6.67 & 67.07 & $8,883,300$ \\
\hline Yemen & E & $(0.37)$ & 1,143 & (1.29) & NA & NA & NA & NA & 5.77 & $25,209,802$ \\
\hline World & NAP & 2.68 & 9,832 & 2.90 & 85.02 & 109.95 & 5,290 & 4.15 & 122.95 & $7,133,924,855$ \\
\hline
\end{tabular}

The comparison of GDP per capita between countries yields a substantial gap, as illustrated in table 1: while oil exporters such as Qatar, Kuwait, UAE, Bahrain, Saudi Arabia, and Oman (all are GCC countries) enjoy wealth derived from natural resources, the others lag considerably behind, being under the world average of 9,832 USD. GDP growth for most of the countries in the sample is above the world average which is not a surprise as Claessens and Yurtoglu (2013) show that emerging countries' growth rates are more than double the growth rates of developed countries. Qatar, Iraq, the West Bank and Gaza, Saudi Arabia, and the UAE have the highest growth rates of the sample countries. These economies, except the oil importer, the West Bank, 
and Gaza, appear to invest their wealth derived from natural resources in overall economic development. The high fluctuation in oil prices forced these countries to diversify their investments and reduce their oil dependence. Therefore, the adoption of a corporate governance code is essential for these countries because it shields them from the abuse of shareholders, encourages investment, helps develop capital markets, and ultimately fosters economic growth (Paredes, 2005).

Regarding stock market development, which is measured by market capitalization as a percent of GDP, we observe high variation among countries, ranging from $22.64 \%$ in Tunisia to $85.68 \%$ in Jordan, and all countries except Qatar and Jordan are far below the world average. In addition, market capitalization ratios are below the average of developed countries (90\%) (Claessens and Yurtoglu, 2013). The value level of traded stocks as a percent of GDP is even worse. All countries are far below the world average of 109.95\%. Except for Saudi Arabia at 57.16\%, all countries are under $20 \%$. These stock market ratios are closely related to the number of listed companies in the stock markets of the region, which ranges from 43 companies in Qatar to 245 in Jordan. These ratios show the need to enhance market mechanisms in these countries. Thus, the adoption of well-developed corporate governance codes plays a major role in protecting shareholder interests from expropriation by managers and controlling shareholders (Paredes, 2005).

With respect to the depth of credit information to the private sector, which is measured by a scale ranging from 0 (low) to 8 (high), most MENA countries are above 6, which shows enough depth of credit information to the borrower. However, the amount of domestic credit provided to the private sector as a percentage of GDP is below the world average. Although Lebanon, Tunisia, Jordan, Kuwait, Bahrain, and the United Arab Emirates are ahead of the other countries, they are far below the world average of 122.95. This indicates that regardless of whether the country is an oil-exporting or oil-importing country, it does not sufficiently provide financial support to the private sector. The probable alternative interpretation is that the weak growth rate of the private sector is correlated with low credit provision.

\subsection{Worldwide Governance Indicators}

The Worldwide Governance Indicators (WGIs) are six dimensions measuring the perception of citizens regarding the governance and institutional quality of their countries (Table 2). These indicators are based on data collected from over 30 sources using more than one organization from over 200 countries (Kaufmann et Al., 2011). WGIs are used in research as a measurement for institutional quality and governance (Daniel et Al., 2012). WGIs are measured as an estimated range, from approximately -2.5 to +2.5 and as a percentile ranking from 0 to 100 (WGI, 2017). Daniel et al. (2012) examine the relationship between the WGI and corporate governance practice and find that the relationship was positively correlated, indicating that the development of corporate governance codes is affected by the development of the national institutions and the improvement of the governance indicators. WGI are determinants for shaping corporate governance rules and systems, motivating the engagement of stakeholders, and increasing the focus of corporate governance codes on shareholders' interests (Zahra, 2014). Therefore, WGIs play an important role in the formation of corporate governance codes. 
TABLE 2 Definitions of Worldwide Governance Indicators

\begin{tabular}{|c|c|}
\hline WGI & Definition \\
\hline $\begin{array}{l}\text { Voice \& } \\
\text { accountability (VA) }\end{array}$ & $\begin{array}{l}\text { "Capturing perceptions of the extent to which a country's citizens are able to } \\
\text { participate in selecting their government, as well as freedom of expression, } \\
\text { freedom of association, and a free media." }\end{array}$ \\
\hline $\begin{array}{l}\text { Political stability } \\
\text { (PS) }\end{array}$ & $\begin{array}{l}\text { "Capturing perceptions of the likelihood that the government will be } \\
\text { destabilized or overthrown by unconstitutional or violent means, including } \\
\text { politically motivated violence and terrorism." }\end{array}$ \\
\hline $\begin{array}{l}\text { Government } \\
\text { effectiveness (GE) }\end{array}$ & $\begin{array}{l}\text { "Capturing perceptions of the quality of public services, the quality of the } \\
\text { civil service and the degree of its independence from political pressures, the } \\
\text { quality of policy formulation and implementation, and the credibility of the } \\
\text { government's commitment to such policies." }\end{array}$ \\
\hline $\begin{array}{l}\text { Regulatory quality } \\
\text { (RQ) }\end{array}$ & $\begin{array}{l}\text { "Capturing perceptions of the ability of the government to formulate and } \\
\text { implement sound policies and regulations that permit and promote private } \\
\text { sector development." }\end{array}$ \\
\hline Rule of law (RL) & $\begin{array}{l}\text { "Capturing perceptions of the extent to which agents have confidence in and } \\
\text { abide by the rules of society, and in particular the quality of contract } \\
\text { enforcement, property rights, the police, and the courts, as well as the } \\
\text { likelihood of crime and violence." }\end{array}$ \\
\hline $\begin{array}{l}\text { Control of } \\
\text { corruption (COC) }\end{array}$ & $\begin{array}{l}\text { "Capturing perceptions of the extent to which public power is exercised for } \\
\text { private gain, including both petty and grand forms of corruption, as well as } \\
\text { "capture' of the state by elites and private interests." }\end{array}$ \\
\hline
\end{tabular}

Source: Kaufmann et al. (2011)

Table 3 shows the average WGI for the MENA countries as measured in percentile rank for the period 2010-2015, which is obtained from the World Bank. It indicates that Saudi Arabia has the least freedom of expression, free media, freedom of association and the ability of people to select their government leaders (voice and accountability). In contrast, Tunisia is the highest-ranked country in voice and accountability. It is noted also that all MENA countries are measured as lower than the world average (50) in voice and accountability.

Qatar and the UAE are ranked highest in the quality of contract enforcement, property rights and rules within society. Libya and Yemen are considered the lowest-ranked countries in terms of rule of law. From the regulatory quality perspective, Libya is found to be the lowest-ranked country in promoting private sector development, while Oman has the highest regulatory quality.

Qatar has the highest political stability rank compared to other MENA countries, while Iraq, Syria, and Yemen have the lowest political stability rank due to their high political disturbance that has continued after the Arab Spring. UAE is ranked as having the highest quality of public service compared to other MENA countries, while Libya and Yemen are perceived as having the lowest quality of public services. 
TABLE 3

\section{Worldwide Governance Indicators of MENA Countries}

\begin{tabular}{|l|l|l|l|l|l|l|}
\hline Countries & COC & GE & PS & RQ & RL & VA \\
\hline Egypt, Arab Rep. & 33 & 27 & 9 & 34 & 39 & 18 \\
\hline Iraq & 6 & 12 & 3 & 11 & 3 & 16 \\
\hline Jordan & 61 & 58 & 29 & 57 & 65 & 26 \\
\hline Kuwait & 57 & 53 & 52 & 52 & 63 & 30 \\
\hline Lebanon & 18 & 43 & 6 & 49 & 27 & 34 \\
\hline Libya & 3 & 6 & 13 & 3 & 9 & 13 \\
\hline Morocco & 47 & 51 & 32 & 50 & 51 & 28 \\
\hline Oman & 62 & 62 & 65 & 68 & 68 & 19 \\
\hline Qatar & 84 & 78 & 87 & 72 & 80 & 23 \\
\hline Saudi Arabia & 57 & 57 & 33 & 55 & 62 & 3 \\
\hline Syrian Arab Republic & 8 & 16 & 4 & 10 & 16 & 4 \\
\hline Tunisia & 55 & 54 & 26 & 44 & 53 & 40 \\
\hline United Arab Emirates & 83 & 85 & 73 & 73 & 70 & 20 \\
\hline Yemen, Rep. & 7 & 9 & 1 & 23 & 9 & 10 \\
\hline
\end{tabular}

Khan (2006) explains the causality relationship between corruption, governance and economic development and identifies two consequences for this relationship. First, if corruption and low governance are the reasons for reducing economic growth, then poor countries should reduce corruption and establish good governance to ensure good economic development. Second, highincome countries are more able to allocate more funds for law enforcement, reducing corruption and ensuring good governance. Accordingly, countries should achieve economic development to reduce corruption and implement good governance. Overall, corruption is associated with low corporate governance. It is clear from Table 3 that corruption is also a major problem in most MENA countries as seven countries (Egypt, Iraq, Lebanon, Libya, Morocco, Syrian Arab Republic, and Yemen) are below average. This can be an indication for low governance.

\section{METHODOLOGY}

This paper investigates the corporate governance codes of MENA countries and their content. If a country has issued more than one code, we examine the code that is issued for non-financial listed companies. Furthermore, to avoid the double counting of codes, we include only the final 
version of each code. When analyzing the content of the codes, we focus on the main areas. These areas include corporate governance disclosures, stakeholders', institutional investors', shareholders' rights and the responsibilities of the board of directors. The analysis of the codes is based on a checklist of 83 items extracted from the OECD principles. With the checklist, we evaluate whether the items mentioned in OECD principles can be found within a specific code. All the checklist items" existence can be represented with a simple " 1 " or " 0 ". " 1 " means that the code contains a recommendation for a specific item of best practice specified in the OECD principles, which is assumed to contribute to improving corporate governance practices. " 0 " means that a recommendation is not present. Therefore, the higher the total sum of the checklist items are, the more code is converged with OECD principles and is assumed to contribute to corporate governance practice improvement. Obviously, a code contributes to enhancing corporate governance when the companies comply with the code recommendations and when compliance leads to changes in corporate governance practice.

We build a comprehensive database of codes of corporate governance for a sample of 16 countries. Therefore, this study offers one of the first comprehensive systematic analyses of the content, variability, and convergence of the MENA national corporate governance codes. Regarding the procedure to codify the items into codes, three coders initially developed the coding scheme for the sample, which has corporate governance codes available in English and Arabic. For consistency, our database includes only corporate governance codes per se. We exclude laws or legal regulations, reports on compliance with codes, consulting firm reports, and individual company codes. The actual national corporate governance codes and data related to the dates of code adoption were mostly obtained from the European Corporate Governance Institute website (ECGI, 2018).

Consequently, we undertook a systematic online search, beginning with the website of the issuer as identified by ECGI, and then progressing to various stock exchange, industry, and government websites to search for the latest versions of the codes. Then, we split the codes into two subsamples (English and Arabic) and assigned each subsample to two different coders to codify them independently. Then, we matched every two sets of data to measure inter-rater reliability using the percentage agreement (Dewey, 1983). We found a high percentage of agreement of between 85 percent and 93 percent among the coders, which is an appropriate level of reliability. Finally, some items required further discussion and reconciliation due to a disagreement between the coders, and these were revised jointly to resolve the inconsistencies. An agreement was reached, and some elements were re-coded.

As long as the corporate governance challenges are determined by the countries' economic and institutional environments, we performed a further analysis to investigate the extent to which corporate governance codes may reflect both countries' economic environments as well as key aspects of institutional environments for each country. Using this analysis, we attempted to identify patterns of association between institutional settings and the quality of the country code to explain the drivers behind convergence or divergence of corporate governance codes.

\section{RESULTS}

In this section, we present the results under the following five subtitles: Diffusion of the codes, convergence/divergence of the codes, peculiarities of the codes, association of economic indicators with the codes, and association of governance indicators with the codes. 


\subsection{Diffusion}

We describe our set of sample codes in Table 4. The table presents a listing of the codes' initial adoption dates, the year of their first and most recent code revision, the total number of code revisions, the identity of their issuers, the application basis, references to OECD or any other transnational codes, and the title of the last code.

\section{TABLE 4}

\section{Corporate Governance Codes of MENA Countries}

\begin{tabular}{|c|c|c|c|c|c|c|c|c|c|c|}
\hline COUNTRY & $\begin{array}{l}\text { Issuing } \\
\text { Entities }\end{array}$ & $\begin{array}{l}\text { Year of } \\
\text { the first } \\
\text { adoption }\end{array}$ & $\begin{array}{l}\text { Year of } \\
\text { the first } \\
\text { revision }\end{array}$ & $\begin{array}{l}\text { Year of } \\
\text { last } \\
\text { revision }\end{array}$ & $\begin{array}{l}\text { Number } \\
\text { of } \\
\text { revisions }\end{array}$ & $\begin{array}{l}\text { All codes } \\
\text { including } \\
\text { revisions } \\
\text { as of } \\
2016\end{array}$ & $\begin{array}{l}\text { Delay in } \\
\text { code } \\
\text { adoption }\end{array}$ & $\begin{array}{l}\text { Comply or } \\
\text { explain }\end{array}$ & $\begin{array}{l}\text { Reference to } \\
\text { transnational } \\
\text { CODES }\end{array}$ & $\begin{array}{l}\text { Year and } \\
\text { Title of Last } \\
\text { Code }\end{array}$ \\
\hline Egypt & $\begin{array}{l}\text { Egyptian } \\
\text { Institute of } \\
\text { Directors at } \\
\text { the Egyptian } \\
\text { Financial } \\
\text { Supervisory } \\
\text { Authority }\end{array}$ & 2005 & 2011 & 2016 & 2 & 3 & 3 years & Voluntary & OECD & $\begin{array}{l}\text { (2016) The } \\
\text { Egyptian code } \\
\text { for Corporate } \\
\text { Governance }\end{array}$ \\
\hline Jordan & $\begin{array}{l}\text { Ministry of } \\
\text { Industry and } \\
\text { Trade }\end{array}$ & 2008 & 2012 & 2012 & 1 & 2 & 6 years & $\begin{array}{l}\text { Comply or } \\
\text { Explain }\end{array}$ & OECD & $\begin{array}{l}(2012) \\
\text { Jordanian } \\
\text { Corporate } \\
\text { Governance } \\
\text { Code }\end{array}$ \\
\hline Kuwait & $\begin{array}{l}\text { Capital } \\
\text { Markets } \\
\text { Authority }\end{array}$ & 2013 & 0 & 0 & 0 & 1 & 11 years & Comply & No Reference & $\begin{array}{l}\text { Co13) } \\
\text { Corporate } \\
\text { Governance } \\
\text { Regulations for } \\
\text { Companies } \\
\text { Regulated by } \\
\text { Capital } \\
\text { Markets } \\
\text { Authority }\end{array}$ \\
\hline
\end{tabular}




\begin{tabular}{|c|c|c|c|c|c|c|c|c|c|c|}
\hline Morocco & $\begin{array}{l}\text { Ministry of } \\
\text { Economic } \\
\text { and General } \\
\text { Affairs }\end{array}$ & 2008 & 0 & 0 & 0 & 1 & 5 years & $\begin{array}{l}\text { Comply or } \\
\text { Explain }\end{array}$ & OECD & $\begin{array}{l}\text { Moroccan } \\
\text { Code of Good } \\
\text { Corporate } \\
\text { Governance } \\
\text { Practices }\end{array}$ \\
\hline Palestinian & $\begin{array}{l}\text { Capital } \\
\text { Market } \\
\text { Authority }\end{array}$ & 2009 & 0 & 0 & 0 & 1 & 7 years & $\begin{array}{l}\text { Comply or } \\
\text { Explain }\end{array}$ & OECD & $\begin{array}{l}\text { (2009) Code of } \\
\text { Corporate } \\
\text { Governance in } \\
\text { Palestine }\end{array}$ \\
\hline Qatar & $\begin{array}{l}\text { Capital } \\
\text { Market } \\
\text { Authority }\end{array}$ & 2009 & 0 & 0 & 0 & 1 & 8 years & $\begin{array}{l}\text { Comply or } \\
\text { Explain }\end{array}$ & $\begin{array}{l}\text { OECD, BIS, } \\
\text { ICGN, IIF }\end{array}$ & $\begin{array}{l}\text { (2009) } \\
\text { Corporate } \\
\text { Governance } \\
\text { Code for } \\
\text { Companies } \\
\text { Listed in } \\
\text { Markets }\end{array}$ \\
\hline $\begin{array}{l}\text { Saudi } \\
\text { Arabia }\end{array}$ & $\begin{array}{l}\text { Capital } \\
\text { Market } \\
\text { Authority }\end{array}$ & 2006 & 2010 & 2010 & 1 & 2 & 4 years & Comply & No Reference & $\begin{array}{l}\text { Corporate } \\
\text { Governance } \\
\text { Regulations }\end{array}$ \\
\hline Syria & $\begin{array}{l}\text { Central Bank } \\
\text { of Syria }\end{array}$ & 2009 & 0 & 0 & 0 & 1 & 8 years & $\begin{array}{l}\text { Comply or } \\
\text { Explain }\end{array}$ & No Reference & $\begin{array}{l}\text { Governance } \\
\text { Guide for } \\
\text { Conventional } \\
\text { Banks } \\
\text { Operating in } \\
\text { the Syrian } \\
\text { Arab Republic }\end{array}$ \\
\hline Tunisia & $\begin{array}{l}\text { Arab } \\
\text { Institute of } \\
\text { Business } \\
\text { Managers } \\
\text { and the } \\
\text { Center of } \\
\text { International } \\
\text { Private } \\
\text { Enterprise } \\
\end{array}$ & 2008 & 0 & 0 & 0 & 1 & 6 years & $\begin{array}{l}\text { No } \\
\text { application } \\
\text { basis }\end{array}$ & No Reference & $\begin{array}{l}\text { Code of Best } \\
\text { Practices of } \\
\text { Corporate } \\
\text { Governance }\end{array}$ \\
\hline Yemen & $\begin{array}{l}\text { The Yemeni } \\
\text { Businessmen } \\
\text { Club (YBC) } \\
\text { and the } \\
\text { Center for } \\
\text { International } \\
\text { Private } \\
\text { Enterprise } \\
\text { (CIPE) }\end{array}$ & 2010 & 0 & 0 & 0 & 1 & 8 years & Voluntary & OECD & $\begin{array}{l}\text { Corporate } \\
\text { Governance } \\
\text { Code }\end{array}$ \\
\hline
\end{tabular}

The first formal adoption of a national code of corporate governance for our sample countries occurred in 2002 in Oman. Oman was the first country in the region to issue a code of corporate governance for companies whose shares are listed on the Muscat Securities Market. The most recent adoption examined in this study occurred in 2013 in Kuwait. Interestingly, among our sample countries, Oman has revised its code four times. This is followed by Egypt, which has revised its code two times. A few have revised their codes only once (Jordan, Lebanon, and Saudi Arabia). One of the most distinguishing features of the remainder of the countries is that they have never revised their codes. 
It is important to understand who the issuers of corporate governance codes are in different countries. Identifying these actors provides information regarding the source of motivation (Aguilera and Cazurra, 2004). The issuer type indicates why codes are developed and how strongly they are enforced. The type of corporate governance code issuers includes (1) the capital market authority in five countries (Kuwait, Oman, Qatar, Palestine and Saudi Arabia); (2) the government in four countries, when the issuer is one of its ministries (Ministry of Small and Medium Enterprises and Handicraft in Algeria, Ministry of Industry and Commerce in Bahrain, Ministry of Industry and Trade in Jordan and Ministry of Economic and General Affairs in Morocco); (3) a directors' association, only in Egypt (Egyptian Institute of Directors); (4) managers' association, only in Tunisia (Arab Institute of business managers); (5) investors' association, only in Yemen (Yemeni Businessmen's Club); (6) stock exchange, only in Libya; and (7) other bodies such as the Lebanese Transparency Association, Central Bank of Syria and Dubai SME.

Efficiency and legitimation trigger corporate governance code adoption. Efficiency is mostly endogenously driven, while legitimation could be exogenously motivated. The issuer type explains the institutional pressure and the motivation to develop a corporate governance code. Coercive isomorphic pressures exist when codes are issued by investors' bodies and by the stock exchange to enhance efficiency. In these cases, the code instructions are included in the requirements for publicly traded firms, as well as demands from institutional investors. In contrast, normative isomorphism pressures exist when the codes are issued by directors' associations and the government to maintain legitimacy. Last, mimetic isomorphism may exist when codes are issued by managers' associations because other successful peer associations might have adopted such codes.

We find that most of the codes were issued by the capital market. This reveals the active role of coercive issuers. Endogenous forces stimulate codes adoption in MENA countries to improve the efficiency of the corporate governance system; however, exogenous forces appear to be weak in MENA countries. These countries are not heavily influenced by globalization, information technology development or opening of financial markets to international investors. Although half of the sample countries refer to the OECD principles as a reference for preparing the corporate governance code, there is neither harmonization of corporate governance systems nor convergence between the codes in MENA countries, as we will see later. Endogenous forces may cause divergence of the content of corporate governance codes in MENA due to different institutional settings. The content of the codes tends to reflect the peculiarities of each country's distinct institutional environment. This means that the adopted governance principles in the codes are 'decoupled' from legitimation concerns and focus more on efficiency goals.

The codes of the MENA countries are, when mentioned, non-legally binding and mostly based on voluntarily or the "comply-or-explain" principle, allowing companies to diverge from corporate governance codes principles. The deviation in applying code principles may reflect specific characteristics of corporate governance systems of MENA countries as endogenous forces.

\subsection{Convergence/divergence of the Codes}

Based on the checklist of the details that were highlighted in the methodology section, we investigated the convergence/divergence of MENA countries' codes to the OECD principles 
under seven subsections; scope, reference to the regulatory framework, shareholder rights, stakeholder rights, institutional investors, board responsibilities, and disclosure (Table 5). In doing so, we wanted to outline the strengths and weaknesses of the codes for each specific section and the overall quality of each country's code.

Overall, there is wide variation among countries regarding the convergence level to OECD principles, ranging between 31\% and 73\%. The high-scoring countries include Morocco (73\%), Kuwait (72\%), Bahrain (66\%), Egypt (61\%), Qatar (60\%), and Jordan (60\%), whereas the lowscoring countries are the United Arab Emirates (31\%), Libya (43\%), and Algeria (43\%) (Table 5). The following subheadings highlight the extent of the convergence/divergence of the codes between MENA and the benchmarking of OECD principles.

TABLE 5

Coverage of Codes of MENA Countries

\begin{tabular}{|c|c|c|c|c|c|c|c|c|c|}
\hline COUNTRIES & 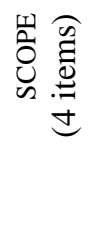 & 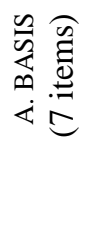 & 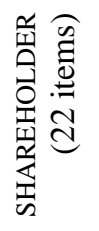 & 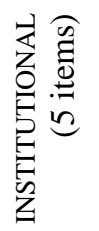 & 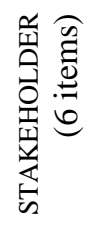 & 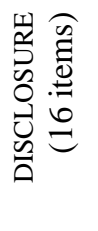 & 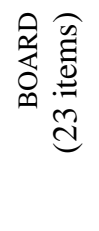 & 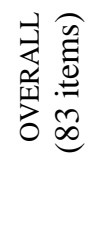 & 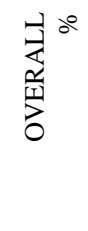 \\
\hline Algeria & 3 & 5 & 15 & 0 & 2 & 1 & 10 & 36 & $43 \%$ \\
\hline Bahrain & 4 & 6 & 11 & 1 & 1 & 11 & 21 & 55 & $66 \%$ \\
\hline Egypt & 4 & 4 & 9 & 0 & 2 & 14 & 18 & 51 & $61 \%$ \\
\hline Jordan & 3 & 3 & 11 & 1 & 4 & 12 & 16 & 50 & $60 \%$ \\
\hline Kuwait & 1 & 5 & 18 & 0 & 4 & 10 & 22 & 60 & $72 \%$ \\
\hline Lebanon & 1 & 2 & 15 & 0 & 2 & 11 & 16 & 47 & $57 \%$ \\
\hline Libya & 1 & 2 & 12 & 0 & 1 & 5 & 15 & 36 & $43 \%$ \\
\hline Morocco & 3 & 4 & 18 & 0 & 4 & 12 & 20 & 61 & $73 \%$ \\
\hline Oman & 1 & 3 & 5 & 0 & 0 & 12 & 20 & 41 & $49 \%$ \\
\hline Palestine & 2 & 5 & 15 & 0 & 3 & 6 & 18 & 49 & $59 \%$ \\
\hline $\begin{array}{l}\text { Qatar } \\
\text { Saudi }\end{array}$ & 1 & 4 & 11 & 0 & 3 & 12 & 19 & 50 & $60 \%$ \\
\hline Arabia & 1 & 4 & 12 & 2 & 3 & 5 & 18 & 45 & $54 \%$ \\
\hline Syria & 0 & 3 & 5 & 0 & 3 & 9 & 20 & 40 & $48 \%$ \\
\hline Tunisia & 0 & 2 & 9 & 0 & 3 & 7 & 20 & 41 & $49 \%$ \\
\hline UAE & 1 & 3 & 7 & 0 & 1 & 6 & 8 & 26 & $31 \%$ \\
\hline Yemen & 4 & 3 & 13 & 0 & 4 & 9 & 14 & 47 & $57 \%$ \\
\hline
\end{tabular}

\subsubsection{Scope}

This subsection includes four classifications to ascertain the scope of each code in terms of the companies targeted by the code, such as listed or non-listed companies or both, or SMEs. The results indicate that the codes predominantly address listed companies. This implies that the 
codes aim to regulate stock markets and mitigate agency problems. Enhancing the stock markets could be motivated by either the efficiency that refers to the demand for codes from investors or the legitimacy that refers to the interest in attracting foreign investments. Furthermore, Tunisian and Syrian codes do not address a specific and clear target, which is the missing link between the codes and their implementers. On the other hand, while some codes concern only listed companies (Saudi Arabia, Oman, Kuwait, Lebanon, Qatar, Libya), some other countries (Jordan, Bahrain, Morocco, Yemen, Egypt) address almost all types of companies, including listed and non-listed companies and SMEs.

\subsubsection{Reference to Regulatory Framework}

This dimension investigates the aim of the code, whether it refers to the regulatory framework, enforcement of compliance, and other issues, comprising seven items. The results revealed that all countries except Syria outline the aim of the code; refer to the regulatory framework in some way, excluding Libya; and highlight the application basis (i.e., comply or explain), excluding Lebanon and Tunisia. However, only $50 \%$ of the codes receive the support of stock market regulation, and only Palestinian and Bahraini codes mandate the compulsory adoption of the principles of the codes; none addresses the cross-border co-operation of regulators in formulating the codes.

\subsubsection{Shareholder Rights}

This section investigates the extent to which codes articulate the rights of shareholders. Providing shareholders with information on a timely and regular basis, equitable treatment of all shareholders, voting in general meetings, electing a board of directors, the rights of minority shareholders, and the right to question the board are among the commonly cited principles. Most of the codes underline rights of shareholders to place an item on the agenda of general meetings, participate in corporate decisions, have information about the date, location, and agenda of general meetings, and proxy voting. However, some issues have received very little attention, such as the establishment of anti-takeover devices, secure ownership registration, cross-border voting, approval of dividend distributions by shareholders, approval of any changes in economic or voting rights, shareholder approval of compensation schemes, the rights of different classes of shareholders, and electronic voting in absentia. Surprisingly, one of the basic rights of shareholders, such as dividends, was not mentioned by seven codes.

\subsubsection{Stakeholder Rights}

The analysis indicates that the stakeholders' section, which contains six items, is one of the weakest sections of the codes. While most of the codes mention the rights of stakeholders, including information rights, they fail to address the redress of stakeholders for violations of their rights, stakeholders' communication rights with the board, and creditor rights, with a few exceptions. Employee participation in corporate governance is cited in seven codes. 


\subsubsection{Institutional Investors}

This subsection reports the results of the analysis regarding the evaluation of whether the codes consider the interaction with and rights and responsibilities of institutional investors. The results indicate that this is the weakest section of MENA countries' codes; they almost never touch the issue, with a few exceptions (Jordan, Saudi Arabia, Bahrain). Thus, these countries have yet to explore the power of institutional investors on certain policies of companies (David et al., 1998; David et al., 2001).

\subsubsection{Board Responsibilities}

The board responsibility section, which comprises 23 items, is one of the strengths of the MENA codes. The analysis results have shown that all codes establish the criteria for board composition and independence. The majority clarify the responsibilities of the board, require the establishment of three primary board committees (i.e., audit, nomination, and remuneration), and advise the separation of the roles of chairpersons and the chief executive officer. However, key roles undertaken by independent board members are disclosed by only five countries' codes (Bahrain, Oman, Kuwait, Tunisia, United Arab Emirates). While nine countries address transparency in the board nomination and election process, the remaining seven countries fail to do so. Measuring the boards' performance as well as managerial performance are among frequently addressed topics in MENA codes. To ensure that directors allocate enough time to matters of corporations, half of the codes limit multiple directorships, while the other half do not have any such restriction. In MENA countries, where family ownership and state ownership are high, board nomination, the selection process and the roles of independent board members are critical in the healthy functioning of markets and preserving the rights of individual investors.

\subsubsection{Disclosure}

This section measures the extent to which the codes prescribe the disclosure of 16 specific items. Although disclosure of some themes (i.e., financial information, non-financial information, ownership structure, and executive remuneration) are addressed by most of the codes, disclosure of some items is not common among MENA codes, such as the selection process of directors, the roles and responsibilities of the $\mathrm{CEO}$ and Chair, issues regarding employees and other stakeholders, the quality of auditing and auditor-client relationships. Moreover, information dissemination channels are commonly noted by all codes except one (Algeria).

\subsection{Peculiarities of the Codes}

Codes tend to reflect the peculiarities of each country's distinct governance environment. In this section, we explain the main peculiarities of the national corporate governance codes of the MENA countries.

The Kuwaiti code assigns Rule No. 11 to outline the importance of social responsibility, which highlights that the social responsibility in business relies on two pillars. The first is the company's compliance to act morally according to laws and general norms. The second is sustainable participation to achieve economic and social development through the attraction of 
national labor, improving the living conditions of laborers and their families, the local community, and the whole society and allocating a percentage of the achieved profits for social services and projects, provided that this allocation matches the nature and volume of the company's activities and the achieved profits. In the same context, the Omani code devotes principle No. 13 for corporate social responsibility. It highlights that the company shall mitigate any adverse impact of its activities on the national economy, community or environment at large. Similarly, Section 7 in the Tunisian code highlights the importance of corporate social responsibility because the socially responsible investments feature the most successful companies.

The corporate governance code of the UAE, as issued for SMEs, focus on pillar 9: family governance to set out the family's relationship with the business. It highlights that when the family and business become more complex, families should establish a "family council" to institutionalize cooperation and link the family and the business. In the same vein, the Yemeni code focuses on family governance in its appendix. It states that family businesses should establish a family constitution and a family council. The importance of establishing a family council is mentioned by the Tunisian code as well. Similarly, the Algerian corporate governance code targets mainly small and medium family enterprises. In the first part of the code, Section 3 highlights the challenges that preclude this type of enterprise from continuing and flourishing. Moreover, in the second part, Section 2 presents the relationships of the enterprise with external parties, including public authorities, customers, suppliers, banks, employees and competitors. It focuses on the importance of managing the succession process. This transmission process is also mentioned in the Tunisian code, which assigns Section 9 to good corporate governance practices in family firms.

The corporate governance code of Bahrain assigns principle No. 9 to "Islamic" companies. The code requires that these companies follow the principles of Islamic sharia law. Furthermore, the code highlights that these companies are subject to additional governance requirements and disclosures to provide assurance to stakeholders that they are following sharia principles. Each company should establish a Sharia Supervisory Board consisting of at least three Sharia scholars.

\subsection{Association of Economic Indicators with the Codes}

The examination of the codes' content yielded a wide range of differences based on the checklist we established across countries. As some countries' codes have high convergence, others have low convergence. Thus, they tend to diverge from one another compared to OECD principles. Unfortunately, these variances among countries do not appear to be precisely associated with economic factors. While some oil-rich countries have high convergence with the OECD checklist analysis, others have quite low convergence. Making the same inference for non-oil rich countries is possible. For example, while Kuwait, Bahrain, and Qatar, as oil-rich countries, have codes that strongly converge with OECD principles, other countries in the same league have low converging codes. On the other hand, some non-oil-rich countries have well-developed codes, such as Morocco, Jordan, and Egypt, and some others do not, such as Tunisia and Syria. 
Concerning GDP growth and GDP per capita, there are no consistent findings between high growth and low growth countries. For example, while Kuwait, Egypt, and Jordan are among the low growth countries with relatively high code convergence, Qatar, Palestine, and Bahrain are high growth countries with high convergence rates with OECD principles. Thus, there is no evidence of whether the economic growth is associated with the convergence or divergence of the codes to the OECD principles.

As outlined in the literature review section, stock market development is an important impetus of code development. In the sample, some countries, which have high market capitalization to GDP ratios such as Jordan, Qatar, Bahrain, and Saudi Arabia, have high convergence with OECD principles. On the other hand, Egypt, Lebanon, Palestine, and Tunisia have the lowest market capitalization to GDP ratios. However, the first three countries have above $50 \%$ convergence with OECD principles. Thus, there is no certain and clear link between stock market development and code convergence/divergence.

Across MENA countries, there is great variety in providing credit to the private sector, ranging between $5.77 \%$ (in Yemen) and $95.55 \%$ (in Lebanon) as a percentage of GDP. The highest credit providers, such as Lebanon, Tunisia, Bahrain, Kuwait, and Morocco, have high convergence with OECD principles. Among the lowest credit providers to the private sector, Algeria and Libya have convergence rates of less than 50\%, whereas Egypt, Yemen, and Palestine have convergence rates of more than $50 \%$. Hence, the association between credit provision to the private sector and code development is not explicit.

The economic indicators elaborated above do not appear to be directly linked to the convergence or divergence of the codes with the OECD principles. Therefore, we provide two possible interpretations of the results. First, as countries that have high economic growth rates, market capitalization, and credit provision ratios also have high convergence scores, we find that in these countries, economic efficiency acts as the impetus of code development because this contributes to economic efficiency. Second, countries with poor economic indicators but high convergence might be hoping that code development can improve economic conditions.

\subsection{Association of Governance Indicators with the Codes}

In this section, we investigate the relationship between the governance indicators and the convergence of codes with the OECD principles, through conducting two analyses, to find whether these codes reflect the governance quality. First, we analyzed this relationship by comparing each code convergence level with the overall average of governance indicators for each country, as shown in Figure 1. The results revealed that there is a deviation between the code convergence and the governance quality. It is evidenced that there is a gap between the convergence of codes with OECD principles and governance quality for all countries. Although Qatar and the UAE have good institutional quality, their codes do not converge with OECD principles. This indicates that governance environments are not aligned with the development of corporate governance codes and their convergence with OECD principles.

\section{FIGURE 1}




\section{Overall Governance Indicators and Quality of Code}

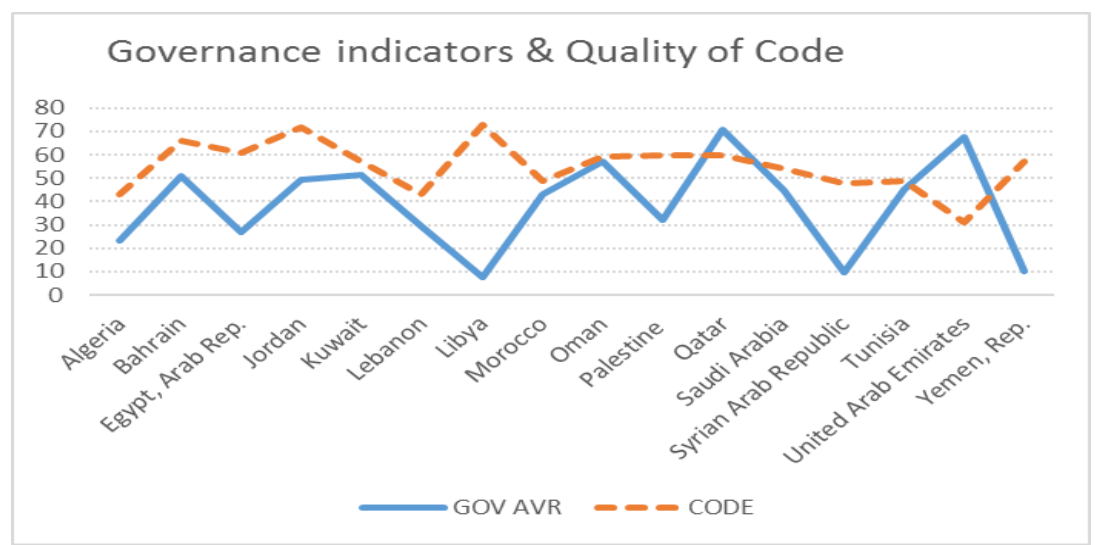

Then, we analyzed this relationship by examining the relationship between each governance indicator and the code convergence, as indicated in Figure 2 demonstrates. Examining the relationship between the COC and the code convergence indicates that the highest level of deviation was clear in Libya, Syria, Yemen, Egypt, Lebanon and Palestine, which means that the codes of these countries are overestimating their actual institutional and governance abilities. In other words, the governance environment is not reflected in code coverage. Examining the relationship between the RQ and the code convergence indicates that the highest level of deviation was clear in Algeria, Egypt, Jordan, Libya, Syria and Yemen. The incompatibility between the PS and code convergence is clearly observable in most countries. Regarding the rule of law, seven countries (Kuwait, Morocco, Oman, Qatar, Saudi Arabia, Tunisia, and the United Arab Emirates) have positive deviations, which means that they have high-quality governance environments in terms of the rule of law, which is not reflected in their code convergence. VA is a clear problem for all MENA countries because all countries are below the code convergence averages level. This indicates that people in these countries are not able to express their opinions or enjoy enough freedom, which might affect the perception of governance quality negatively. The deviation between the code convergence and GE was negative in countries such as Algeria, Egypt, Jordan, Kuwait, Libya, Palestine, Syria, and Yemen.

FIGURE 2

Individual Governance Indicators and Quality of Code

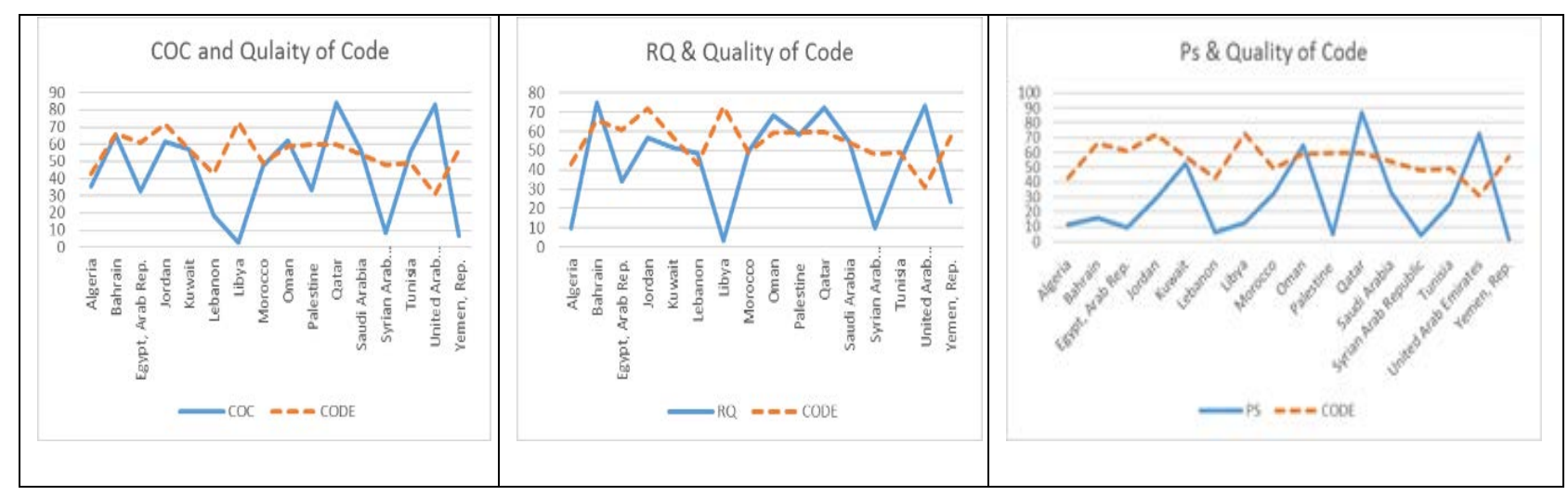




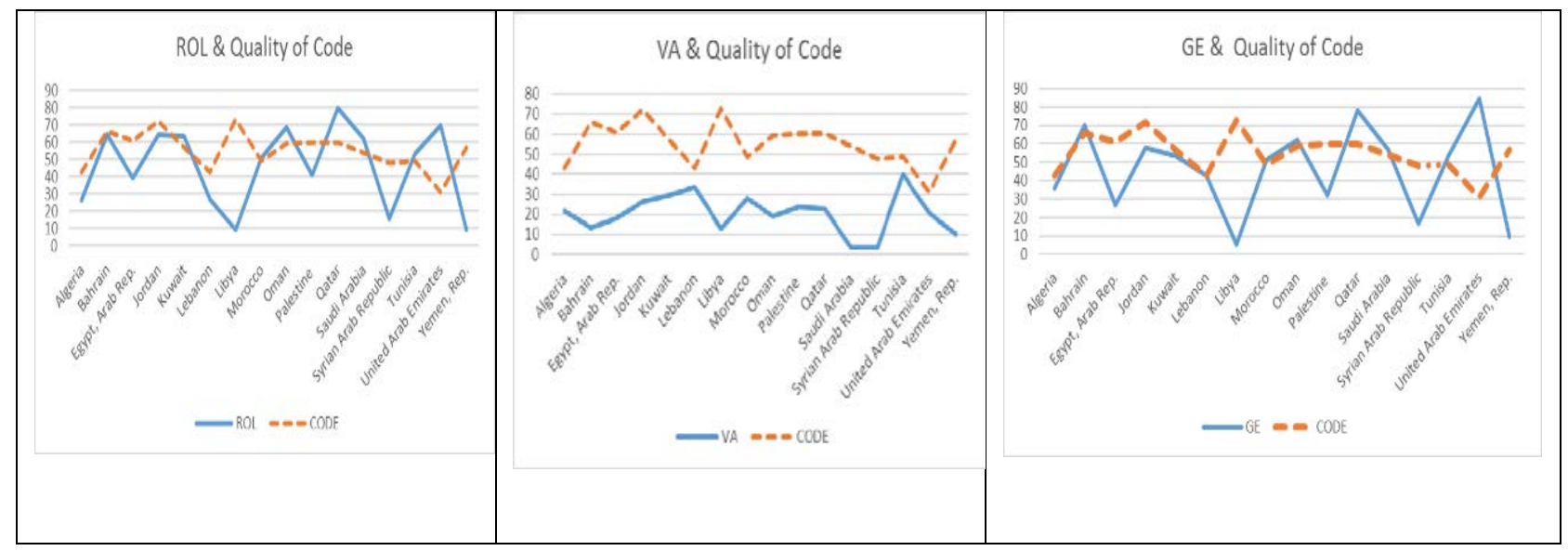

The two-level analysis indicates a gap between the scores of codes convergence and the overall governance quality. Having a good governance environment does not guarantee to have good code.

\section{DISCUSSION AND CONCLUSION}

This study aims at investigating the convergence or divergence of the corporate governance codes between MENA countries and comparing them with the globally known OECD Principles of Corporate Governance. The sample of the study is the corporate governance codes of the MENA countries. The data collection methodology is a qualitative content analysis of the codes, which is supported by a quantitative analysis of the corporate governance convergence and its relationship with economic indicators and governance environment quality.

We have identified that the first formal adoption of a national code of corporate governance in our sample countries occurs in 2002 in Oman, while the most recent adoption examined in this study occurs in 2013 in Kuwait. In the meantime, most of the countries have never revised their codes or have revised them only once, except Oman and Egypt, which revised their codes more than once. With the increase of globalization and the developments regarding corporate governance around the world, MENA countries are expected to modify their codes more often accordingly.

Concerning the issuers of codes in MENA countries, several bodies, including most stock markets and other organizations, initiated the code regulation. This reveals the active role of coercive issuers as endogenous forces; thus, exogenous forces appear to be weak in MENA countries. Moreover, most codes are based on a voluntary or “comply-or-explain” principle, which does not enforce implementation of the code principles. All codes somehow refer to a regulatory framework except Libya; however, only 50\% of the codes are supported by stock market regulation. Furthermore, none of the codes addresses the cross-border co-operation of regulators in formulating the codes.

The analyses of the codes by benchmarking OECD principles revealed that codes commonly enact principles regarding shareholders, board responsibilities, and disclosure, although they do 
not address all expected principles. For example, in shareholders rights, some issues received very little attention, such as cross-border voting, approval of dividend distributions by shareholders, shareholder approval of compensation schemes, rights of different classes of shareholders, and electronic voting in absentia. Surprisingly, one of the basic rights of shareholders, dividends, is never mentioned by seven codes. In the board responsibilities section, all codes are not equivalently transparent in the board nomination and election process which is a primary mechanism in alleviating agency problems; thus, they are advised to consider this point in further code amendments. The disclosure sections of the codes can also be better formulated by highlighting several major issues for transparency, such as the selection process of directors, the roles and responsibilities of the CEO and Chair, and issues regarding employees and other stakeholders because disclosure is the only means for outsiders to obtain information from the company. However, the codes are overall weak in referring to stakeholder rights and institutional investors. This might be attributable to the lack of institutional investors in the ownership structure of corporations as most of these countries depend on family businesses.

The economic factors elaborated in the relevant section do not appear to be directly linked to the convergence or divergence score of the codes to the OECD principles. Therefore, we provide two alternative inferences from the results. First, countries that have high economic growth rates, market capitalization, and credit provision ratio also have high convergence scores. In these countries, economic efficiency acts as the impetus of code development, or code development contributes to economic efficiency. Second, countries with poor economic factors that have high convergence scores might be hoping that code development can serve for the improvement of economic conditions. This means that the adopted governance principles in the codes are 'decoupled' from legitimation concerns and focus more on efficiency goals.

The governance environment and the institutional quality of MENA countries are not aligned with their codes. A deviation between the average governance and code convergence was addressed in most MENA countries. Syria, Yemen, Libya, Palestine, and Egypt are found to have the most deviations, and they face many problems in terms of COC, GE, RL, RQ, VA, and PS. The main reason for these deviations is related to their political instability and the Arab Spring revolutions. The UAE and Qatar have good governance environments, although their codes are not as compatible with OECD principles, especially the UAE.

The study provides several important implications and lessons to be learned for the regulators, firms and other stakeholders. First, the adoption of corporate governance codes of MENA countries is relatively late compared to those of developed countries. To close the gap and stay competitive in the global market, they need to strive for the enactment of best practices of corporate governance principles immediately and revise them in a timely manner. Although some of the countries (i.e., Oman and Egypt) within the sample of the study have updated their codes several times, others have not done yet so. Second, the regulatory bodies of corporate governance codes are quite diverse in these countries. This is good to learn the expectations of different stakeholders and consider and utilize their diverse experiences in the code development process. However, although capital market authority is the primary regulators in most of the countries, it is not in some others. We recommend those countries to incorporate capital market authority into the code development process to better consider the expectations of investors both 
local and foreign as well as individual and institutional. This is a principal requirement to mitigate agency problems and to make firms attractive for domestic and foreign investors.

Third, "comply-or-explain" or "voluntary" base of adoption of the codes is non-legally binding. These countries need to assess the adoption degree of the codes by the firms under this condition. If regulators recognize that it opens the door for significant deviations from the principles or major non-compliance of the codes, they may need to consider replacement of them with "comply" base. Fourth, all codes need to determine their scopes and target organizations precisely so that the implementers will position themselves accordingly. Fifth, weakly structured sections of the codes (i.e., shareholder rights, stakeholder rights, and institutional investors) need to be strengthened in the next revisions. Indeed, to improve the development of the codes, regulators are recommended to listen to various stakeholders such as institutions, implementers, and investors so that they will find the opportunity to address missing principles. Sixth, we could not find a consistent trend between economic development and coverage of the codes in this study which might be because most of the countries have developed their codes in recent years. Thus, it might yet be early to assess their effect on economic development. A similar study that will be replicated later might yield more stable and interesting results. Alternative explanations have been already provided in the preceding sections on the association between coverages of the codes and economic development.

Moreover, the gap between macro governance environment and development of high-quality code might signal a lack of interaction between two sides. Cooperation between institutions and regulators (i.e. code developers) during the code development process to produce a high quality code is advised. In addition, for these countries to integrate into world economy and lessen their dependence on oil and gas through diversification, enactment of high quality codes is of crucial importance. Finally, during the code development process, firms, investors, and other stakeholders should be invited to share their opinions and experiences because they might have different perspectives than regulators. A corporate governance code commission might be established involving representatives of a variety of stakeholders (Krenn, 2016). This is likely to enhance and contribute better development and implementation of the principles of the codes.

The study has few limitations. Although we attempted to establish a comprehensive checklist of items, it is not exhaustive, which can be modified for further studies. Second, even though we have taken all the possible precautions to secure the reliability of the data collection, there is a limitation inherent in qualitative studies. Third, the study is limited to MENA countries. For further studies, the methodology of the paper can be adopted in other countries and regions. 


\section{REFERENCES}

Aguilera, R. V. \& Cuervo-Cazurra, A., 2009. Codes of good governance. Corporate Governance: An International Review. 17, 376-387.

Aguilera, R. V., \& Cuervo-Cazurra, A. 2004. Codes of good governance worldwide: what is the trigger? Organization Studies. 25, 415-443.

Aguilera, R., Florackis, C., \& Kim, H. 2016. Advancing the Corporate Governance Research Agenda. Corporate Governance: An International Review. 24, 172-180.

Aguilera, R.V. \& Jackson, G. 2010. Comparative international corporate governance. The Academy of Management Annals. 4, 485-556.

Al-Malkawi, H. A. N., Pillai, R., \& Bhatti, M. I. 2014. Corporate governance practices in emerging markets: The case of GCC countries. Economic Modelling. 38, 133-141.

Bremer, J., \& Ellias, N. 2007. Corporate governance in developing economies -The case of Egypt. International Journal of Business Governance and Ethics. 3(4) pp. 430-445.

Cicon, J. E., Ferris, S. P., Kammel, A. J., \& Noronha, G. 2012. European corporate governance: A thematic analysis of national codes of governance. European Financial Management, 18, 620-648.

Claessens, S., \& Yurtoglu, B. B. 2013. Corporate governance in emerging markets: A survey. Emerging Markets Review. 15, 1-33.

Collier, P. \& Zaman, M. 2005. Convergence in European corporate governance: The audit committee concept. Corporate Governance: An International Review. 13, 753-768.

Cromme, G. 2005. Corporate governance in Germany and the German corporate governance code. Corporate Governance: An International Review. 13, 362-367.

Cuomo, F., Mallin, C. \& Zattoni, A. 2016. Corporate Governance Codes: A Review and Research Agenda. Corporate Governance: An International Review. 24, 222-241. 
Daniel, S. J., Cieslewicz, J. K., \& Pourjalali, H. 2012. The impact of national economic culture and country-level institutional environment on corporate governance practices. Management International Review. 52, 365-394.

David, P., Hitt, M.A. \& Gimeno, J., 2001. The influence of activism by institutional investors on R\&D. Academy of management Journal. 44, 144-157.

David, P., Kochhar, R. \& Levitas, E., 1998. The effect of institutional investors on the level and mix of CEO compensation. Academy of Management Journal. 41, 200-208.

Davies, M., \& Schlitzer, B. 2008. The impracticality of an international “one size fits all” corporate governance code of best practice. Managerial Auditing Journal. 23, 532-544.

Dewey, M. E. 1983. Coefficients of agreement. British Journal of Psychiatry. 143, 487-489.

ECGI. 2016. Index of Codes. www.ecgi.org (Accessed during November 2017).

Farooq, O \& AbdelBari, R. 2013. Effect of property rights on the relationship between legal traditions and corporate governance: Evidence from the MENA region. International Journal of Business Governance and Ethics. 8 (3). pp. 224-241.

Farooq, O. \& Chetioui, Y. 2012. Corporate governance and stock price performance of firms during the crisis: evidence from the MENA region International Journal of Business Governance and Ethics. 7(4). pp. pp.331 - 349

Farooq, O. \& Seffar, M. 2012. Corporate governance and its effect on the liquidity of a stock: evidence from the MENA region. International Journal of Business Governance and Ethics. 7 (3). pp. 232-251.

Greco, G., Ferramosca, S. \& Marchi, L. 2015. Governance codes and types of issuer a global study. International Journal of Business Governance and Ethics. 10(1). pp. 28-56.

Hermes, N., Postma, T. J. B.M., \& Zivkov, O. 2006. Corporate governance codes in the European Union: Are they driven by external or domestic forces? International Journal of Managerial Finance. 2, 280-301.

Hermes, N., Postma, T.J.B.M. \& Zivkov, O. 2007. Corporate governance codes and their contents: an analysis of Eastern European codes. Journal for East European Management Studies. 12, 53-74.

Heugens, P. P. M. A. R., \& Otten, J. A. 2007. Beyond the dichotomous worlds hypothesis: Towards a plurality of corporate governance logics. Corporate Governance: An international review. 15(6). pp. 1288- 1300.

WGI. 2017. Worldwide Governance Indicators. http://databank.worldbank.org/data/reports.aspx?source=Worldwide-Governance Indicators accessed 12/3/2017 2:41pm

Humphries, S \& Whelan, C. 2017. National culture and corporate governance codes. Corporate Governance: The International Journal of Business in Society. 17,152 - 163.

Kamal Hassan, M. 2012. A disclosure index to measure the extent of corporate governance reporting by UAE listed corporations. Journal of Financial Reporting and Accounting. 10, 4-33.

Kaufmann, D., Kraay, A., \& Mastruzzi, M. 2011. The worldwide governance indicators: methodology and analytical issues. Hague Journal on the Rule of Law. 3, 220-246.

Krenn, M. 2016. Convergence and divergence in corporate governance: An integrative institutional theory perspective. Management Research Review. 39(11). pp.1447-1471.

Nadal, N. I. C. K. 2013. Corporate governance post 'Arab spring'in the Middle East and North Africa. Law in Transition. 6, 52-61. 
Nizaeva, M. \& Uyar, A. 2017. Corporate governance codes of Eurasian Economic Union countries: a comparative investigation. Corporate Governance: The International Journal of Business in Society. 17 (4). pp.748-769.

OECD 1999: OECD Principles of Corporate Governance, Paris: OECD.

OECD Principles. 2015. G20/OECD Principles of Corporate Governance. OECD Publishing, Paris.

Omet, G. 2005. Ownership structures in MENA countries: listed companies, state-owned, family enterprises and some policy implications. In MENA Regional Corporate Governance Forum: Advancing the Corporate Governance Agenda in MENA. http://www. oecd. org/dataoecd/26/2/35402110. pdf.

Omran, M. M., Bolbol, A., \& Fatheldin, A. 2008. Corporate governance and firm performance in Arab equity markets: Does ownership concentration matter? International Review of Law and Economics. 28, 32-45.

Ovsiannikov K. 2017. Corporate Governance Reforms in Japan: Instilling the New Regime. Cogent Business \& Management. 4. 1300993

Paredes, T. A. 2005. Corporate governance and economic development. Regulation, 28: 34-39

Piesse, J., Strange, R., \& Toonsi, F. 2012. Is there a distinctive MENA model of corporate governance? Journal of Management \& Governance. 16(4), 645-681.

Roberts, G. H. 2004. Convergent capitalisms? The internationalisation of financial markets and the 2002 Russian Corporate Governance Code, Europe-Asia Studies. 56,1235-1248.

Schiehll, E., \& Martins, H. C. 2016. Cross

-National Go Review and Assessment. Corporate Governance: An International Review. 24, 181-199.

Solomon, J. \& Solomon, A. 2004. Corporate Governance and Accountability, Wiley, Chichester.

Webb, R., Beck, M., \& McKinnon, R. 2003. Problems and limitations of institutional investor participation in corporate governance, Corporate Governance: An International Review. 11, 65-73.

Zahra, S. A. 2014. Public and corporate governance and young global entrepreneurial firms. Corporate Governance: An International Review. 22,77-83.

Zattoni, A. \& Cuomo, F. 2008. Why adopt codes of good governance? A comparison of institutional and efficiency perspectives. Corporate Governance: An International Review. $16,1-15$. 